\title{
Cantaria em louvação ao dia do Barroco Mineiro e homenagem ao poeta e ensaísta Affonso Ávila
}

\author{
Cristina Ávila*
}

É com profunda comoção que, em nome de minha família, agradeço a prestigiosa homenagem concedida pela Pontifícia Universidade Católica de Minas Gerais - PUCMinas e pela Assembleia Legislativa do Estado de Minas Gerais ao reconhecido e saudoso poeta e ensaísta do Barroco Mineiro, Affonso Ávila. O convite para a participação neste debate acadêmico, feito ao próprio homenageado pela Prof. Dra. Melânia da Silva Aguiar, foi recebido por ele com enorme entusiasmo, mas quis o destino que ele se fosse antes da data prevista. Como historiadora da arte e cultura estou presente apenas para contemplar alguns aspectos de sua obra, especialmente no que se refere aos estudos de Barroco, mas não posso substituir o depoimento do ensaísta que seria, com certeza, bem mais interessante.

Curioso por natureza, leitor infatigável e perfeccionista em sua veia literária, Affonso Ávila criou uma poesia de natureza telúrica e vanguardista, inspirada pelos processos fundamentais da cultura mineira. Foi estudando documentos e questionando o senso comum da controversa ideia de mineridade que sentiu o desejo de compreender teoricamente as origens do homem montanhês, que teria um senso peculiar ao exercer simbolicamente o dúbio papel de geratriz econômica do ouro para a metrópole e um senso rebelde de busca de um ideal libertário surgido em variadas revoltas e conflitos, de que são exemplos a Guerra dos Emboabas e a Conjuração Mineira. Assim, aponta prioritariamente a formação de uma mentalidade pautada em três premissas, as quais foram teorizadas no livro $\mathbf{O}$ lúdico e as projeções do mundo barroco (ÁVILA, 1975). Seriam essas:

1. Via de intenção e impacto persuasórios oriunda da doutrina contrarreformista decretada pelo Concílio de Trento (1545-1563) e o poder do Estado Absolutista;

2. O primado do visual apoiado na ideia da sugestão ótica, quer na valorização de cor, luz e paisagem no espaço arquitetônico, plástico, coreográfico, musical, mas sobretudo através de seu uso cotidiano formador de uma mentalidade ou

* Universidade Federal de Minas Gerais - UFMG. 
estilo de vida de ampla práxis social e intenção persuasória;

3. O receptor incorpora o sentido lúdico através da ambiguidade da curva e da contra-curva, vertente que se manifesta no discurso literário e artístico como um todo. O jogo de palavras e formas contempla o ilusório, metafórico e redundante até toda estrutura de criação, em que o profano e o sagrado dão as mãos à configuração de toda vida religiosa e social da época.

O incansável batalhador em prol da expressão do Barroco Mineiro acabou por se debruçar, em meio às pesquisas na década de 1960, sobre dois textos setecentistas que deram origem ao mais importante estudo teórico sobre o tema já escrito. Trata-se do livro Resíduos seiscentistas em Minas (1999) - que traz o fac-símile dos textos do Triunfo eucarístico e do Auro trono episcopal. É assim que, sem alarde, antecipa os hoje tão badalados estudos das mentalidades e da história da cultura, revelando as festas barrocas religiosas como de cunho sagrado e profano. Em suas próprias palavras, essas têm "o estado de euforia da sociedade mineradora, que se faz expandir através de festas mais de regoizijo dos sentidos, que propriamente de comprazimento espiritual.” (ÁVILA, 1999). Affonso Ávila viu nessas primeiras manifestações festivas a origem do espirito de carnavalização brasileira.

Além de poeta e estudioso do Barroco, destacou-se também como critico literário e intrépido articulador e promotor de ações em defesa do Barroco, sendo um dos responsáveis pela fundação do Instituto Estadual do Patrimônio Histórico e Artístico de Minas Gerais - IEPHA-MG. Dono de grande sensibilidade e generosidade, foi grande incentivador de talentosos pesquisadores e jovens poetas, recebendo-os com a mesma gentileza que acolhia intelectuais de ressonância internacional.

Sua dedicação se estendia especialmente à formação de novas gerações de pesquisadores, como se vê em três livros fundamentais para os que dão os primeiros passos na teoria da arte barroco-rococó mineira, dois desses encontrados apenas em sebos: Iniciação ao barroco mineiro (1984) e o pequeno (mas fundamental) texto introdutório do Barroco mineiro: glossário de arquitetura e ornamentação (1996).

Em 2004 publica Circularidade da ilusão, onde reúne textos esparsos publicados em catálogos de luxo de grandes exposições internacionais e congressos de pouco acesso a um público em formação. Neste livro, ele lança a teoria do "Barroco Estradeiro", baseado na informação e difusão do estilo através do trânsito por vários arraiais coloniais, de artistas como Antônio Franciso Lisboa - dito o Aleijadinho - e Manoel da Costa Athaide, parceiros em obras do porte 
da Igreja de São Francisco de Assis, em Ouro Preto, e do Conjunto dos Passos da Paixão em Congonhas do Campo.

Nessas andanças pela Estrada Real, especialistas renomados influenciaram novos artistas, e o caso exemplar é a pintura do forro da nave da Igreja de Santo Antônio de Itaverava, quando Athaide passou os truques do azulejo fingido para artistas anônimos que executaram os painéis laterais que contam, ao modo de quadrinhos ilustrados e através de paráfrases populares, os milagres do santo padroeiro. Com família originária de Itaverava, Ávila não se cansou de lutar até conseguir o tombamento nacional da matriz da localidade.

Outra faceta do autor foi a de agitador cultural, tanto no âmbito da literatura quanto na promoção de eventos e publicações de vanguarda, no estudo crítico da arte - principalmente por meio da Revista Barroco, iniciada em 1969. Já em seu primeiro número, a iniciativa apresentou-se como fórum de ideias e debates aos principais historiadores da arte, contemporâneos de Ávila, unindo brasileiros e estrangeiros, sem qualquer resquício de provincianismo.

Secretariada por Hélio Gravatá, em sua primeira fase, e por José Arnaldo Coelho de Aguiar Lima, a revista tem, entre seus colaboradores, assíduos nomes como o do saudoso diretor do Louvre, Germain Bazin, e grandes pensadores da arte brasileira, como Benedito Nunes, Curt Lange, Carlos Del Negro, Myriam Ribeiro de Oliveira, Nelson Aguilar, Henry Maldiney, entre diversos outros de gerações posteriores.

Em 2012, o conjunto da sua obra - que perpassa os anos de 1953 até abril último, quando lançou Égloga da maçã - foi reconhecido com o Prêmio Governo de Minas Gerais de Literatura.

Mesmo desolado com o descaso que via na política, que era insensível à projeção dos estudos acadêmicos, do turismo histórico-cultural e da conservação dos acervos móveis e imóveis do Barroco, ainda queixava-se da dificuldade de recursos para projetos voltados ao estudo do estilo e, sobretudo, da continuidade da Revista Barroco, que cessara para ele no inadimisível número 19, número impar que considerava de mau gosto editorial. Mesmo assim, um dia antes de sua morte me convocou para discutir a possibilidade de chegarmos ao menos até o número 20 e me entregou um texto inédito que gostaria que fosse introdutório da Revista, além de um texto também inédito do grande amigo, poeta, tradutor e ensaísta Haroldo de Campos, que deveria constar nas páginas de destaque do possível número 20 que, como o número 19, deveria ser organizado e dirigido por mim. Imposta a mim - filha e parceira de estudos coloniais mineiros - esta responsabilidade enorme, recorri a diversos e possíveis patrocinadores para a 
execução do que seria a última coletânea de artigos que coroaria a fase clássica dos estudos do Barroco no Brasil. Diversos estudiosos contemplaram e colaboraram com o envio gratuito de trabalhos sobre o tema ou a ele correlatos, entre brasileiros e estrangeiros.

Estamos agora diante da importante iniciativa da Assembleia Legislativa de criar o dia do Barroco Mineiro e de festejar o bicentenário do Aleijadinho, sonho do poeta, que soube no livro Cantaria barroca (1975) unir duas paixões - a de pesquisador e poeta - da Cidade Patrimônio da Humanidade. Neste livro, também esgotado, cantou seus bens mais emblemáticos - como se Ouro Preto fosse uma musa ou amante de sua preferência.

Coube a ele e a minha mãe, a poeta Laís Corrêa de Araújo, nos proporcionar acesso às diversas manifestações artísticas. Eu e meus irmãos crescemos numa casa cheia de livros e de projetos culturais, privilégio que pretendemos reverenciar com a preservação da memória de nosso pai e de seu ideal de ver Minas Gerais como grande centro de turismo gerador de recursos para manter preservadas as suas cidades históricas - das mais esquecidas às mais reverenciadas.

Gostaria de finalizar minhas palavras como herdeira da felicidade que Affonso Ávila encontraria nessas mais que necessárias, primorosas ações póstumas de acadêmicos, apreciadores da arte e da literatura, dos sensíveis membros da Assembleia Legislativa de Minas Gerais, particularmente, do excelentíssimo Deputado Estadual e Presidente Diniz Pinheiro, cujo apoio será fundamental para a publicação do periódico, com os versos minimalistas do livro Cantaria barroca, que virá anexado à publicação da Barroco 20, em que o poeta homenageia o nosso artista síntese do Barroco Brasileiro - Antônio Francisco Lisboa - o Aleijadinho:

São Francisco de Assis

$\&$ pelo partido se conhece a arquitetura

$\&$ pela portada se conhece o arquiteto.

(ÀVILA, Data, p. )

A família agradece com muito orgulho e emoção as homenagens, títulos e medalhas que agradariam imensamente ao nosso pai - Affonso Ávila. Muito obrigada. 


\section{Referências}

ÁVILA, Affonso. O lúdico e as projeções do mundo barroco. São Paulo: Perspectiva, 1980.

ÁVILA, Afonso. (Org.) Resíduos seiscentistas em Minas: textos do século do ouro e as projeções do mundo barroco. Belo Horizonte, Editora da UFMG, 1999. ÁVILA, Affonso. Iniciação ao barroco mineiro. São Paulo: Nobel, 1984.

ÁVILA, Affonso. Barroco mineiro: glossário de arquitetura e ornamentação. Belo Horizonte. Mineiriana, 1996.

ÁVILA, Affonso. Circularidade da ilusão. São Paulo: Editora Perspectiva, 2004. Barroco. nº 1 , Belo Horizonte, 1969. 
